\title{
Policy Challenges for Open Economies
}

\author{
Pedro Cerqueira ${ }^{1} \cdot$ Francisco Serranito $^{2} \cdot$ Camélia Turcu $^{3}$ (D)
}

Accepted: 20 December 2021 / Published online: 5 January 2022

(C) The Author(s), under exclusive licence to Springer Science+Business Media, LLC, part of Springer Nature 2021

This special issue contains a selection of nine policy-relevant peer-reviewed articles in the field of international (macro)economics. These papers include empirical contributions as well as theoretical approaches and were presented at the INFER ${ }^{1}$ Annual Conference 2020 organized online by the Sorbonne Paris Nord University (France). They provide new insights into the analysis of monetary and fiscal policies in open economies and put a particular focus on the labor and capital mobility.

A first group of papers investigates the migration-governance nexus, the capital mobility over the long term, as well as countries' ability to tap international capital markets for funds, based on the quality of their fiscal governance.

Jordi Ripollés and Inmaculada Martinez-Zarzoso investigate in their paper "African Asylum Seekers in Europe: The Interplay between Foreign Aid and Governance in Origin Countries" the effect of governance quality-in the country of origin - on asylum migration from African countries to EU economies and evaluate the extent to which official development aid acts as a catalyst. The data covers 51 African origin countries and 24 European destination countries over the period from 1996 to 2018. Different gravity model specifications are used. The results show that asylum flows are strongly determined by governance quality in the origin country and this result depends on the amount of foreign aid received from developed economies. Moreover, it is further shown that development aid is reducing the number of African asylum applications in Europe only when the level of governance quality in

\footnotetext{
${ }^{1}$ INFER is a non-profit organization supporting science and research in all areas of economics. It currently has more than 250 active members and several institutional members, across 37 countries on five continents, as well as a large circle of more than 1,000 occasional participants and supporters. INFER encourages scientific discussion during workshops on specific topics as well as hosting annual conferences. It also offers numerous publication possibilities to its members.
}

Camélia Turcu

camelia.turcu@univ-orleans.fr

1 University of Coimbra, CeBER, Faculty of Economics, Coimbra, Portugal

2 Sorbonne Paris Nord University, CEPN, Paris, France

3 University of Orléans, LEO, Orléans, France 
the origin country is relatively high. The opposite is true in the case of lower levels of governance in the origin country. The results hold regardless of whether or not the country of origin was a beneficiary of the European Union Emergency Trust Fund (EUTF) whose aim is to support stability, security and resilience in African economies and thus to improve living conditions of potential migrants in their home countries.

Mariam Camarero, Alejandro Muñoz and Cecilio Tamarit, in the paper "50 Years of Capital Mobility in the Eurozone: breaking the Feldstein-Horioka Puzzle" examine the issue of capital mobility in the EU over the long term. More specifically, they apply recent panel and time series cointegration techniques allowing endogenous breaks to the long-run saving-investment relationship for two different periods: 1970-2019 using annual data and 1995-2019 with quarterly datain the case of 19 core and peripheral Eurozone countries. For a given country, if there is evidence of no cointegration between savings and investments then the authors conclude in favour of the perfect capital mobility hypothesis. They further introduce endogenous multiple structural breaks with the aim of analysing the impact of historical events on capital mobility. Three main results are obtained in the empirical analysis. Firstly, capital mobility has been increasing since the 70s and most particularly after the Maastrich Treaty has been signed. Nevertheless the path of capital mobility has also been affected by major events: the EMS crisis, the German reunification, the USSR downfall and the financial crises. Secondly, capital mobility is less pronounced in peripheral European countries compared to core ones even if European economic integration has triggered huge capital flows from core to periphery. Thirdly, the impact of the recent financial crises (the global financial crisis and the sovereign debt crisis) on capital mobility are mixed. Financial crises have decreased capital mobility for peripheral countries and for some countries its level has not been recovered yet, whereas for core countries no effects have been detected. Hence, if for core countries the Feldstein-Horioka puzzle disappeared along with the process of the European economic integration, it is still observed for many peripheral countries after the financial crises.

Kady Keita, Gene Leon and Frederico Lima in their paper "Do financial markets value quality of fiscal governance?" ask the question of whether financial markets value the quality of fiscal governance for a panel of 173 countries over the period 1996 to 2016. They hypothesize that fiscal governance is a key signal to investors about the creditworthiness of a particular country and that better fiscal governance can improve a country's access to market-based external finance. Credit ratings are used to proxy financial markets perceptions. In particular, to test their hypothesis, the authors measure market access by: the probability of issuing bonds, the probability of having a credit rating by at least one of the three main credit rating agencies, the average rating by the three main rating agencies and the bond spreads. The fiscal governance is measured first by rather broad indicators like the government effectiveness index of the World Bank and then in a second step, it is captured through granular data on fiscal governance from Public Expenditure and Financial Accountability (PEFA) assessments. Their findings suggest that stronger fiscal governance is associated with improvements in market access. Especially measures related to the transparency of public finances (i.e. Public Financial Management 
practices like budget transparency and reporting) together with a better debt management help to improve a country's access to external finance. This result is explained by the fact that better fiscal governance reduces the perception of risk by investors and improves access to market-debt.

Next, we gather together several articles that analyze uncertainty shocks, exchange rates and monetary policies.

The paper "Foreign and Domestic Uncertainty Shocks in Four Open Economies" by Rachatar Nilavongse, Michał Rubaszek, Karsten Staehr and Gazi Salah Uddin analyzes the macroeconomic effects of domestic and United States (US) economic policy uncertainty shocks in four open economies (Canada, UK, South Korea and Sweden) with floating exchange rates. The authors estimate a Bayesian VAR model describing the dynamics of ten local and US variables for each of the four countries, and further use it to evaluate the response of the system to structural shocks. The results suggest that an unexpected rise in global economic uncertainty, seen as a US Economic Policy Uncertainty (EPU) shock, has a negative impact on real sector activity in each of the four analyzed economies, although the impact differs across the countries. Domestic uncertainty shocks seem also to have a negative impact on local production, but the reaction is heterogeneous across countries. A key finding concerns the role of the exchange rate in the process of adjustment: the real effective exchange rates in the US and in the domestic economies react differently to uncertainty shocks. Increased economic uncertainty in the US triggers a real appreciation of the US dollar which can amplify the effects of uncertainty on the US economy. In the four open economies under consideration, a surge in both the foreign (US) and domestic economic uncertainty always leads to a real depreciation of the domestic currency. This moderates the real effects of uncertainty shocks and illustrates the role of the US dollar as a safe haven in turbulent times.

Guido Traficante explains in the paper "Uncertain potential output: implications for monetary policy in a small open economy " what is the impact of measuring potential output with a noise on the conduct of monetary policy. The theoretical framework relies on a new Keynesian DSGE small open economy model. The small economy hypothesis implies that potential output can be affected by either domestic productivity shocks or foreign (potential output) shocks. Potential output will be considered as uncertain if the central bank and the private sector are unable to distinguish perfectly the domestic and the foreign component of a shock. In this case, as it is not possible to perfectly observe the state of the economy, a Kalman filtering will be used to estimate it. Incomplete information will affect the understanding of the overall volatility in the economy. Indeed, a positive productivity shock (i.e. an increase of the domestic component of potential output) will be interpreted by the central bank and private agents as both an increase in domestic productivity and a decrease of foreign output. Simulating the model will provide the three main following results. First, as a result of incomplete information, the economic agents will significantly underestimate the size of the productivity shock. So an ex-ante increase of the potential output will have lower expansionary effects. The presence of uncertainty could then justify the adoption of simple rules. Second, Taylor rules that guarantee the largest welfare are those which respond to inflation only and do not include an exchange rate 
component which can be interpreted as a floating exchange rate regime. Finally, if the inflation coefficient is low then both with complete and incomplete information, there exists a set of parameters in the monetary rule such that the exchange rate peg is always preferable to an independent monetary policy.

The paper "Collateral Misrepresentation, External Auditing, and Optimal Monetary and Supervisory Policies" by Fatih Tuluk aims at introducing the external auditing literature in a standard DGSE model with financial frictions. If there is an information asymmetry about the quality of the bank's asset portfolio, then the introduction of an audit sector may reduce the incentives of a bank to falsify its collateral value. A key assumption of the model is that the cost of verifying the quality of a bank's assets increases with the production of audit services and the intensity of central bank supervision. Furthermore, if one assumes that banks can misrepresent their assets by obtaining fraudulent audits, then financial frictions will be higher and banks will have an incentive to reduce their lending to the economy. The paper seeks to model what would be the optimal policies to mitigate these financial frictions and increase lending from the banking sector. Three major lessons can then be drawn from the model. First, the low interest rate policy leads to an increase in the demand by banks for high quality audit services if the cost associated to fees for dodgy audits is sufficiently low. This leads to a welfare loss due to the overproduction of high quality audit services by the banking sector. Second, market discipline by itself will be insufficient to correct this market imperfection. Indeed, banks will always have an incentive to avoid the rules or to adapt to them. Therefore, central banks must intervene with an optimal supervisory policy to mitigate these incentive problems in order to reduce costly private audits. Finally, this paper shows that optimal supervisory policy will not eliminate all incentive problems in the banking sector. Moreover, the paper highlights that financial frictions are not only caused by banks, but also by the institutions that design and implement supervisory policies.

Further, a group of papers that analyze fiscal policies' related issues in open economies will follow.

António Afonso, João Tovar Jalles and Ana Venâncio, in their paper "Structural Tax Reforms and Public Spending Efficiency" assess the effects of structural tax reforms on the degree of efficiency of the public sector in terms of minimizing the distortionary growth and income distribution effects, and to help governments to offer public services more efficiently. More specifically, for a sample of 18 OECD countries over the period 2006-2017, the authors use a new "narrative" database of tax changes in the personal income tax (PIT), corporate income tax (CIT) and the value added tax (VAT) and proceed in three steps. First, they compute a composite indicator of government efficiency; second, the authors compute the input-efficiency scores, and finally, using a panel framework controlling for possible sources of endogeneity, they estimate the impact of the tax changes on the public sector efficiency. Their main findings are that increasing tax rates leads to a decrease of the public sector efficiency, mainly due to PIT, while an increase of the tax base improves efficiency. Moreover, 
they find that these effects are distinct and operate differently over different taxes during expansions and recessions. In expansions, increasing the CIT base and reducing the PIT rate improve public sector efficiency, while in recessions, efficiency improves when PIT and VAT bases increase and CIT rate decreases.

Marcelo Santos and Marta Simões, in the paper "Globalization, Welfare Models and Social Expenditure in OECD Countries" study whether the welfare state models influence the impact of the different dimensions of globalization (economic, social, political) on social expenditure, and if this nexus is welfare program-specific or global. More precisely, they use a database of 36 OECD countries over the period 1990-2018 in a panel framework. They control for endogeneity by exploiting exogenous variations in neighbour countries and by imputing missing observations through the EMB algorithm which combines the classic EM algorithm with bootstrapping. The results suggest that the reaction of various welfare specific programs to the different dimensions of globalisation is regime specific but, in most cases, positive. In particular, globalisation has not undermined the ability of the different welfare state regimes to secure social protection (including healthcare) and education. Therefore, the results support the compensation hypothesis which underlines that globalisation is expected to increase social expenditure as voters demand for more state intervention that promotes welfare for all citizens. The findings do not validate the efficiency hypothesis which suggests that higher levels of globalisation result in less social expenditure due to the need to promote international competitiveness through reduced taxation.

Matija Lozej and Graeme Walsh, in the paper "Fiscal Policy Spillovers in a Monetary Union" investigate how fiscal expansions in the Euro Area impact the Irish economy when monetary policy is active or passive. They do this using two different classes of models: a DSGE model (the EAGLE model) and a traditional structural model (the multicountry NiGEM model and the Irish multisectoral COSMO model). The authors simulate a one-year increase in government spending (through consumption or investment) in the remaining euro area and examine how the Irish economy reacts to. They show that the impact on the Irish economy is about $30 \%$ of the multiplier effect in the rest of the euro area, if the monetary policy is passive. However, if the monetary policy is active, the DSGE finds negligible effects, while the traditional model still finds modest spillovers. While the results are similar across models, the channels are quite different. Using the DSGE, the authors find that the spillovers operate mainly through the trade and competitiveness channel and that the interest rate channel cancels the previous effects if monetary policy is active. In the traditional model, the authors prove that the trade channel is the primary channel, while the interest rate effect is very small.

Acknowledgements We wish to thank George Tavlas, Editor of the Open Economies Review, for giving us the opportunity to publish this special issue. We are grateful to the referees, discussants and all participants at the INFER Annual Conference 2020, for their valuable comments and suggestions.

Publisher's Note Springer Nature remains neutral with regard to jurisdictional claims in published maps and institutional affiliations. 